\title{
DAILY PRODUCTION ACTIVITY AT THE ENTERPRISES OF THE MINING URALS DURING THE LATE XIXTH - EARLY XXTH CENTURY
}

\author{
Yuriy D. Korobkov ${ }^{1}$ \\ Svetlana S. Velikanova. ${ }^{1}$ \\ Maxim V. Popov ${ }^{1}$ \\ Alexey G. Ivanov. ${ }^{1}$ \\ Elena A. Ovsyannikova. ${ }^{1}$ \\ Oksana P. Chernykh. ${ }^{2}$ \\ 1. Nosov Magnitogorsk State Technical University \\ 2. Moscow University of Finance and Law MFUA \\ Address: 38 Lenin Avenue, 455000, Chelyabinsk Region, Magnitogorsk, Russia
}

\begin{abstract}
The study of everyday life history, including its production aspects, is one of the leading trends in modern historical science. At the same time, Russian historians in this respect are behind their foreign colleagues because of the negative influence of the Soviet methodology, which focused specialists on the study of macroprocesses. This is especially characteristic of the pre-revolutionary period. This circumstance determines the choice of the research topic. The article focuses on such subjects of production daily routine at the mining enterprises of the Urals as the state of labor qualification, the level of labor motivation, industrial discipline, horizontal and vertical relationships in labor collectives. Their analysis made it possible to come to the conclusion that the mining Ural region at the beginning of the 20th century had mainly patriarchal production relations, which were expressed in the low level of labor discipline, motivation, production qualification of workers, authoritarian-paternalistic style in the intra-group interaction of production subjects.
\end{abstract}

Keywords: mining urals, production activity, enterprises

\section{INTRODUCTION}

\section{Introduction to the problem}

A characteristic feature of modern historiography is the increased interest in the history of everyday life. The subject of an "ordinary" person, his experiences and deeds, has been worked out for a long time and fragmentary in historical research, supplementing the "big" story. Meanwhile, the study of everyday life provides an opportunity to understand how the life of ordinary people evolved in different historical periods, what were their thoughts and feelings, how they perceived historical reality and a deeper understanding of global processes is allowed from the positions of microhistory.

\section{Relevance of the problem}

The history of everyday life opens new possibilities for the epoch study, which means that it allows us to examine the state of society during the period under study in detail, and to revise the established stereotypes. Taking into account the leading role of labor in everyday life of people, the production daily routine is of particular importance among their diverse life practices. Its study allows us to identify the specifics of people interaction in work collectives, to determine the characteristics of their attitude to work, the state of production discipline, to establish the level of labor motivation and the most effective ways of its material stimulation, which is one of the main tasks of any economic system.

\section{Problem study}

The development of various aspects of production daily life of the Ural workers has gone through several stages. Pre-revolutionary authors R. Popov (Popov R., 1874), I.Kh. Ozerov (Ozerov I.Kh., 1910), A.N. Mitinsky (Mitinsky A.N., 1909) focused on such aspects as the state of labor ethics of the 
Ural workers, their level of motivation, production discipline and qualification. In general, all prerevolutionary authors agreed on the significant influence of the Ural industry "original system" on the daily work habits of local workers and the reverse effect of the workers' industrial mentality on the development of mountainous districts.

The main subjects of the working issue Soviet historiography were the number, the composition, the placement of workers, the level of their wages and the duration of a working day, which were considered in the works by B.N. Kazantsev (Kazantsev B.N., 1966), L.A. Beilin, L.I. Borodkina (Beilin L.A., Borodkin L.I., 1960), A.A. Zvorykin (Zvorykin A.A., 1961) and other experts. And in both cases, the study of industrial daily life issue was not put forward as an independent object of the study.

The present stage is characterized by the growth of the research interest in the problem of everyday life, and its promotion to the number of research priorities. This fully applies to the problem of production daily life. Its study was significantly intensified both at the all-Russian level in the works by N.N. Kozlova (Kozlova N.N., 2005), N.B. Lebina (Lebina N.B., 2015), E.Yu. Zubkova (Zubkova E.Yu., 2000), M.N. Fedchenko (Fedchenko M.N., 2009), O.L. Leibovich (Leibovich O.L., 2008), and at the regional level in the works by V.I. Isaev, S.S. Bukin (S.S. Bukin, V.I. Isaev, 2007), M.M. Efimkin (Efimkin M.M., 2008), N.N. Makarova (Makarova N.N., 2009) and other historians. The feature of the modern historiographic situation is that the researchers pay the main attention to the Soviet period. The pre-revolutionary stage was "less fortunate" in this respect, although the need to study and compare production daily life at various stages of historical development is beyond doubt. These circumstances determine the choice of the article topic.

\section{Hypotheses}

The study of the workers' working lives of the mining Urals allows to establish local relationships with the main factors of Russian history at the beginning of the 20th century, including the development of the Russian revolutionary process.

\section{METHODS}

The production everyday life is considered by us as a certain sphere of human everyday life, including the events and the processes that are repeated from day to day in the actions of workers at work, as well as the forms of behavior related to it. The history of production everyday life is the study of everyday circumstances of work, the motivation of work, the state of production discipline, the relationships in labor collectives and other factors of production.

The scientific principles of historicism, objectivity, versatility and subject-activity approach are applied for its study. The work is based on the following special historical and general scientific methods: problem-chronological method, expressed in the study of any part of the problem in chronological order, the method of periodization, according to which the study of facts is carried out within a certain period, which allows to analyze the changes in historical reality, reveal the boundaries of these changes, the beginning of new trends, systemic, logical and statistical methods.

\section{MAIN PART}

One of the system-forming factors of production daily life is the attitude of workers towards work. Its study on the example of the mining workers of the Urals gives rather contradictory picture.

Undoubtedly, labor occupied a huge place in the life of workers. The ethnographers who studied various areas of the mining Ural in the end of the XIXth - the beginning of the XXth century, believed that the Ural workers, as a rule, had more favorable living conditions and eat better than the workers in the industrial centers of European Russia. However, this was achieved due to huge additional labor costs on their part and a strong degree of exploitation.

It is no accident that up to 1917 the Ural workers had no unity with regard to such civilized practice as an 8-hour working day. Along with the requirement for its introduction, there were often the wishes to preserve 12 or even 24-hour shifts with a general motivation - to have more time to work in the

Submit Date: 22.01.2018, Acceptance Date: 26.02.2018, DOI NO: 10.7456/1080MSE/129

Research Article - This article was checked by Turnitin Copyright (C) The Turkish Online Journal of Design, Art and Communication 
household. According to the Ural Mining Department in December 1905 "a worker even prefers a 24hour shift with 2 shifts or 12 hour shift with three shifts in many cases, to devote the next 24 hours to the forest or mowing" (RSHA, F. 48. Inv. 1. C. 230. Sh. 97), and this is due to the debilitating severity of an almost continuous work near the fire.

Serfdom did not make the workers to refuse from striving for quality, a conscientious work, the interest in production improvement, and they offered their "uncomplicated" ways of its rationalization. So, in November 1873, the Dobriansky factory workers applied to the Polazninsky factory office with the request not to allow broken cast iron and rolled metal to be reworked, because "this material does not bring any benefit from experience, but, on the contrary, even harms the better in the furnace ..." Urals ..., 1960). During the strike at the Beloretsk factory in May 1902, it was proposed to transfer the delivery of the billets to the workers who were not engaged in their processing, which, in the opinion of the workers, would speed up the manufacture of finished goods and, accordingly, would raise wages (SASR F. 24. Inv. C. 1039. Sh. 18). Given the availability of skilled personnel and materials "lying around ... the banks of the Kama and throughout the plant as 250 pood billets" the workers of the Motovilikhinsky plant organized a turner guild in May 1917 to produce the articles for the village (Perm Life, 1917. Oct. 6).

At the same time, the real labor practice of the Ural workers gives us a lot of examples of a completely different kind. The contemporaries and the researchers of the mining industry noted such features of labor behavior of workers as restrictionism, low labor discipline (absenteeism and late arrivals were a mass phenomenon at the enterprises of the region), a low level of labor qualification, poor work, drunkenness, the theft during production.

Along with the data of factory and mining statistics, an intuitive picture of labor discipline level is provided by the analysis of documents that determined the internal schedule of factory works (rules, instructions, contract terms, settlement books). Their comparison allows us to formulate the conclusion about its general low level and the timeless stability of its main components.

The agreement of the Chermoz factory management with the craftsmen in May 1863, mentioned such workers' faults as: 1) disobedience, rudeness, insolence, riot, drunkenness, quarrels; 2) the lost and damaged master's property; 3) the absenteeism, late appearance at work, an unauthorized absence from it, the failure to perform the assigned work; 4) theft, fraud (RSHA, F. 37. Inv., 58. C. 371. Sh. 55). The typicality of these violations in the 60-70-ies of the XIXth century is evidenced by the fact that all of them were the grounds for fines, except of drunkenness and theft, for which more serious penalties were applied.

The same situation remains at the turn of the XIX-XX centuries as evidenced by the internal regulations of plants in the West-Yekaterinburg Okrug, which distinguish the following typical violations of labor discipline: 1) untimely appearance or unauthorized absence at work; 2) the non-observance of the rules of caution in the factory premises during the handling with fire; 3 ) non-observance of cleanliness and neatness in the same premises; 4) the violation of silence during the work by noise, screaming, abuse, quarrel or a fight; 5) disobedience; 6) coming to work in a drunken state; 7) the organization of games of chance (cards, pitch-and-toss, etc.). And "fine articles" remained the same as before.). (The state of workers in the Urals ..., 1960).

The peaks of labor discipline fall and the associated decline of labor productivity happened during the revolutionary periods, which is related to the general situation in the country and the peculiar interpretation of the freedoms received by the workers as permissiveness and impunity. This was mentioned in the decisions of meetings and congresses of the Ural industrialists in 1905-1907, in the private statements by the persons of the factory administration and representatives of the Ural Mining Department. Their general position is reflected by the summary of the mining chief of the KamskoVotkinsky mountainous district in November 1906, which linked the overall decline of labor

Submit Date: 22.01.2018, Acceptance Date: 26.02.2018, DOI NO: 10.7456/1080MSE/129

Research Article - This article was checked by Turnitin Copyright (C) The Turkish Online Journal of Design, Art and Communication 
productivity with the mass participation of workers in permanent meetings on the issues of the liberation movement or the opposition to it. In 1917 the situation became even more serious. The general model, typical for the entire Ural industry, is reflected by the complaint of the Kizelovsky Mountain District office to the Perm District Council. In October 1917, his administration noted a significant "decline of discipline and order among the workers", which manifested itself in the refusal to comply with the authority orders, turning an 8-hour working day "almost into a 5-hour", the discussion of any issue at the meetings of workers, "without taking into account the production necessity" (the working class of the Urals ..., 1927).

One of the typical phenomena of the mining industry was theft at the enterprises of the region. It was widespread even during the feudal period, which was facilitated by the general atmosphere at serf enterprises, where "everyone was stealing", according to Popov. Over time, "the earnings" at the expense of factory products turned into a stable household phenomenon, which the authorities had to consider. Moreover, as the governor of the Ufa mountain district noted in 1907, the theft among the workers of enterprises subordinated to him "is considered as valor" (RSIA, F. 48. Inv. 1. C. 234. Sh. 89).

The statistical data which allowed to assess the real scale of this phenomenon, mining and factory reporting are not provided, therefore, it is necessary to use indirect evidence. One of them, reflecting the massive nature of theft in the mining industry, is the widespread practice of searches at factory checkpoints. Their cancellation at the enterprises of the region after the Manifesto on October 17, 1905 led to a sharp increase of factory property theft. In particular, according to the report of the district police officer in December 1905, the workers of the Zlatoust factory, "having obtained the cancellation of searches at factory checkpoints, steal everything daily." (SARF. DPOO, 1906. C. 236. Inv. 6. Sh. 11).

This is also evidenced by the rules for workers recorded in their pay books, which distinguish only two violations during production: drunkenness and "misappropriation of a working tool, manufactured metals, articles, supplies and other factory things without the permission of the factory administration".

A significant influence on the production daily life of the Ural plants was provided by such a stable component of worker psychology as equalization. It was formed under the influence of labor organization mining system even during the pre-reform period, when "half of the entire male population of factories was engaged in mining work; the rest was distributed among minors, the elderly, the incapable of work and occupied by subsidiary factory services, and in the end, it was impregnated with the same mining work in one way or another. The wages of the working people at the factories were scanty, but they were provided for all" (Popov R., 1874).

Despite the abolition of this system during the post-reform period, the equalizing psychology continued to influence greatly on the production practices of the Ural workers. First of all, this manifested itself in the desire to provide everyone with work and the same earnings. Moreover, it characterized the actions of the workers not only in typical situations of various industrial conflicts that occurred on this ground, when, for example, the workers of the Chermoz factory, who achieved $15 \%$ increase of wages as a result of the strike during the winter of 1905-1906, "decided to distribute the total amount of wages among the shops evenly, without giving an advantage to anybody" (The situation of the Ural workers ..., 1960), or in the practice of "zero days", "when two weeks are working ones out of 3 or the work lasts four hours a day in order to provide the work to as many people as possible", but also in new situations for workers. It's about the trying to organize labor artels in the beginning of the XXth century, which were created "on the same principle - to give earnings to as many working people as possible", which limited the qualitative composition of personnel by this tradition.

The production daily routine of the Ural plants was influenced by the peculiarities of intra-group interaction in labor collectives. Despite the administration's disdainful attitude towards its workers, the lack of attention to their interests and the disrespect for their human dignity the bulk of the workers had

Submit Date: 22.01.2018, Acceptance Date: 26.02.2018, DOI NO: 10.7456/1080MSE/129

Research Article - This article was checked by Turnitin Copyright (C) The Turkish Online Journal of Design, Art and Communication 
the patriarchal system of relations and the paternalistic attitudes of mass consciousness in the relationship with the factory administration. A. Uralsky wrote the following: "According to the workers, the entire administration was represented by chiefs, from whom they were completely dependent both in the walls of the factory and at home; the owners of factories were the barins and the "benefactors". When the barins and the "benefactors" arrived in their latifundia and factories ..., the workers took off their hats, went to them to bow, congratulated them on their arrival and, having received vodka, drank to their health" (Uralsky A. Working unions in the Urals of 1905-1907 // Past years, 1908. No. 11. pp. 154-155).

The evidence of the Ural worker commitment to paternalistic values in the process of their interaction with the administration are the criteria for the selection of minor administration representatives. According to P.P. Bazhov "Shosh" (small factory bosses) was recruited from the workers and in most cases tried to get along with them. Because of the dual position of "Shosh" and the need to maneuver between the administration and the workers constantly, the attitude of the craftsmen to it was different: some were considered as the best comrades, others were perceived like the worst enemies" (Bazhov P.P., 1980). The consequence of this, especially during the revolutionary years, was the election of the administration not by professional and business qualities, but by the criterion of "convenience" for the workers. It is no accident that after the February Revolution, according to the Governor of the Alapaevsky Karpov Mountain District, the workers tried "to make such a selection of persons with whom they would like to work closely (RSHA, F. 74. Inv. 316. Sh. 172). The flip side of the patriarchal model during the revolutionary periods is the uncontrollable growth of violence towards the administration, which has taken the form of a universal means of any conflict resolution. It is no accident, that according to the assessment of the Mining Department, the level of violence at the Ural plants exceeded all-Russian parameters.

Among the reasons that influenced the development of production everyday life at the enterprises of the region, first of all, the preservation of the main features of the "original system" of the mining industry and the crisis nature of its post-reform development should be noted until 1917. The organization of production at "free" factories and plants differed little from the previous feudal relations and was restructured very slowly, which reduced the level of labor motivation of workers and did not create an interest in a qualitative and productive work among them.

\section{CONCLUSIONS}

The system of "total" tutelage of the workers at state and private factories that was formed in the mining industry of the pre-reform Urals, "having nothing like this even in the landlord estates of European Russia" (The situation of the workers in the Urals, 1960) formed such qualities as inertia, the lack of initiative, took away "all initiative" from them.

And after the abolition of serfdom, the relapses of pre-reform psychology had a significant impact on their daily production routine. Thus, the striving and the desire to work, the value of labor, the respect for qualitative work, professionalism was combined with a general low level of industrial culture, labor discipline and labor motivation. Thus, the daily production of the Ural workers at the turn of the 19th and 20th centuries can be characterized as the type of everyday life of workers who are at the stage of transition from manufactory to industrial stage of development and therefore combines the features of both.

\section{Conflict of interest}

The authors confirm that the presented data do not contain a conflict of interest.

\section{REFERENCES}

Bazhov P.P. The Urals true stories // Essays in 3 vol. M., 1986. V. 3. pp. 5-77 [in Russian]. Beilin L.A., Borodkin L.I. The origin of socialist competition. M., 1960. 88 p. [in Russian]. 
Bukin S.S., Isaev V.I. Housing problem in the cities of Siberia during the twentieth century. // Humanitarian sciences in Siberia. 2007. № 2. pp. 60-64. [in Russian].

Efimkin M.M. Housing factor in the process of industrial adaptation of Siberia in the XXth - XXIst centuries. // Experience of housing problem solution in the cities of Siberia during the twentieth and the early twenty-first centuries. Novosibirsk, 2008. pp. 3-45. [in Russian].

SARF. DPOO. 1906. C. 236. Inv. 6. Sh. 11. [in Russian].

SASR F. 24. Inv. 16. C. 1039. Sh. 18. [in Russian].

Zvorykin A.A. Socialist competition in the industry of the USSR. M., 1961. 284 p. [in Russian].

Zubkova E.Yu. Post-war Soviet society: politics and everyday life. 1945-1953. M., 2000. 230 p. [in

Russian].

Kazantsev B.N. The growth of real wages and incomes of the USSR industry workers in 1951-1958. // The history of the USSR. 1966. № 3. pp. 10-26. [in Russian].

Kozlova N.N. Soviet people: scenes from history. M., 2005. 527 p. [in Russian].

Lebina N.B. Soviet everyday life: norms and anomalies from military communism to a great style. M., 2015. 483 p. [in Russian].

Leibovich O.L. In the city of M: essays of the social daily life of the Soviet province. 2nd ed. Moscow, 2008. 297 p. [in Russian].

Makarova N.N. From the everyday life of Magnitogorsk: the health system in 1929-1935. // The

problems of Russian History. 2009. № 9. pp. 251-262. [in Russian].

Mitinsky A.N. Mining Urals. St. Petersburg, 1909. 244 p. [in Russian].

Ozerov I.Kh. Mountain plants of the Urals. M., 1910. 255 p. [in Russian].

Perm life. 1917. Oct. 6 [in Russian].

The situation of Ural workers during the second half of the XIXth - the beginning of the XXth century. 1861-1904. M.-L., 1960. 667 p. [in Russian].

Popov, R. Mining Urals // Domestic notes. 1974. № 2. pp. 299-372. [in Russian].

The working class of Urals in the years of war and revolution. Sverdlovsk, 1927. V. 2. 354 p. [in

Russian].

RSHA. F. 37. Inv. 58. C. 371. Sh. 55.

RSHA. F. 48. Inv. 1. C. 230. Sh. 97.

RSHA. F. 48. Inv. 1. C. 234. Sh. 89.

RSHA. F. 74. Inv. 1. C. 316. Sh. 172.

Uralsky A. The union of workers in the Urals during 1905-1907. // Past years. 1908. No. 11. pp. 151-

162. [in Russian].

Fedchenko M.N. The daily life of a Soviet man (1945-1991). Kurgan, 2009. 231 p. [in Russian].

Yuriy Korobkov, Prof. D. of History, Svetlana Velikanova, Ph.D, Zinaida Arakcheeva, Ph.D, Natalia Kozhushkova, Ph.D, Oksana Chernykh, Ph.D, Nadezhda Antipanova, Ph.D // Social and economic adaptation of mining workers of the Urals region in the late of the XIX - the beginning of the XX century // The Turkish Online Journal of Design, Art and Communication. TOJDAC. April 2017 Special Edition. Vol. 7. Pp. 1219-1226. URL: http://www.tojdac.org/tojdac/VOLUME7-

APRLSPCL_files/tojdac_v070ASE248.pdf [in Russian].

Korobkov, Y., Velikanova, S., Arakcheeva, Z., Sannikova, L., Levshina, N., \& Chernykh, O. (2017).

Socio-Cultural Factors of the Russian Reforming Process of the 18-20th Centuries. Journal of History

Culture and Art Research, Special Issue. 6(5), 241-246. doi: http://dx.doi.org/10.7596/taksad.v6i5.1301 